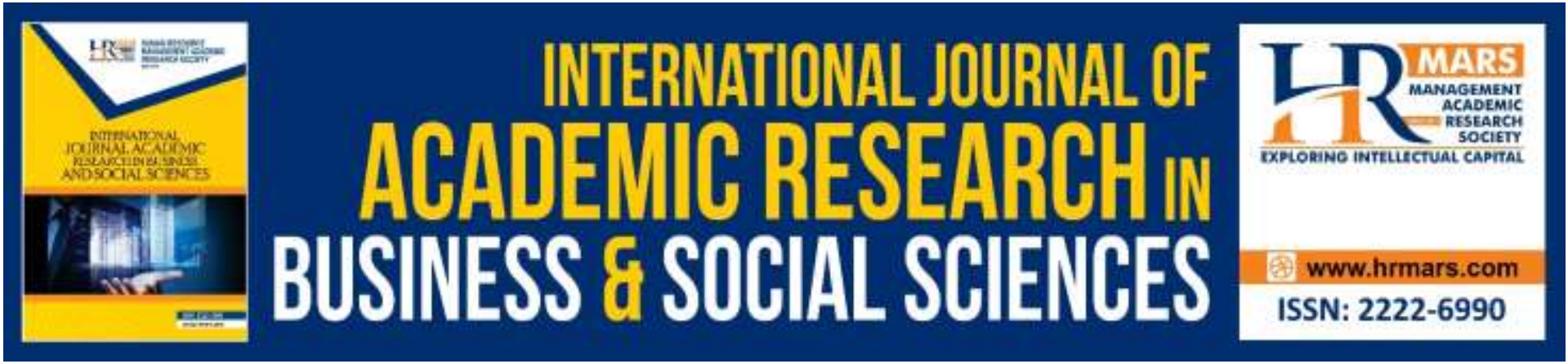

\title{
Feasibility Study on the Imperatives for the Simulation of Ammonia Release Management
}

Abdani Abdul Gafor, Nor Mariah Adam, Mohd Ibrani Shahrimin Adam Assim, Azizul Hakim Lahuri \& Omar Faruqi Marzuki

To Link this Article: http://dx.doi.org/10.6007/IJARBSS/v11-i17/11402

DOI:10.6007/IJARBSS/v11-i17/11402

Received: 04 August 2021, Revised: 01 September 2021, Accepted: 25 September 2021

Published Online: 20 October 2021

In-Text Citation: (Gafor et al., 2021)

To Cite this Article: Gafor, A. A., Adam, N. M., Assim, M. I. S. A., Lahuri, A. H., \& Marzuki, O. F. (2021). Feasibility Study on the Imperatives for the Simulation of Ammonia Release Management. International Journal of Academic Research in Business and Social Sciences, 11(17), 207-216.

Copyright: (C) 2021 The Author(s)

Published by Human Resource Management Academic Research Society (www.hrmars.com) This article is published under the Creative Commons Attribution (CC BY 4.0) license. Anyone may reproduce, distribute, translate and create derivative works of this article (for both commercial and non-commercial purposes), subject to full attribution to the original publication and authors. The full terms of this license may be seen

at: http://creativecommons.org/licences/by/4.0/legalcode

Special Issue Title: Empowering Community and Beyond, iRandau, 2021, Pg. 207 - 216

Full Terms \& Conditions of access and use can be found at http://hrmars.com/index.php/pages/detail/publication-ethics 


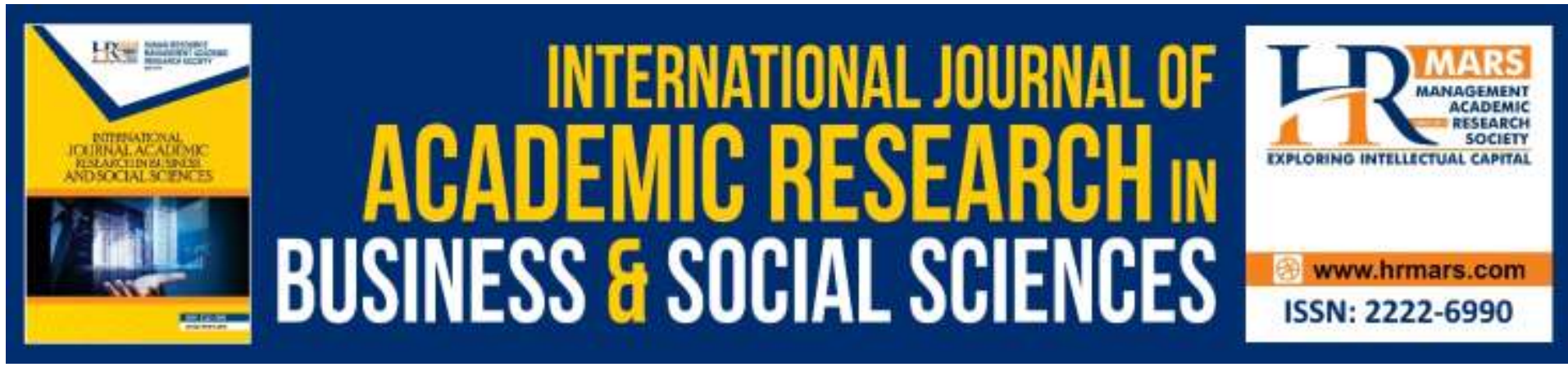

\title{
Feasibility Study on the Imperatives for the Simulation of Ammonia Release Management
}

\author{
Abdani Abdul Gafor ${ }^{1}$, Nor Mariah Adam ${ }^{1}$, Mohd Ibrani \\ Shahrimin Adam Assim ${ }^{1}$, Azizul Hakim Lahuri ${ }^{1}$ \& Omar Faruqi \\ Marzuki ${ }^{1,2}$ \\ ${ }^{1}$ Faculty of Humanities, Management and Science, Universiti Putra Malaysia, Jalan Nyabau, \\ 97008 Bintulu Sarawak, ${ }^{2}$ Institut Ekosains Borneo (IEB), Universiti Putra Malaysia, Bintulu 97008, \\ Sarawak, Malaysia \\ Email: danikb176@yahoo.com
}

\begin{abstract}
Ammonia is being exported through Bintulu Port via pipeline and loaded to the vessel (ship) using marine loading arm. Ammonia is toxic in nature and transferred at $-33^{\circ} \mathrm{C}$. Marine loading arms are special equipment for loading and unloading liquid cargo from the wharf and the vessel with swivel joints, and supplemented by supporting structure, and other accessories. Loading arms have safety features such as that we can set up quick release mechanism, in which the loading arm will decouple from the manifold when there is an emergency, or the movement of vessel is out of range. Studies such as by United Kingdom (UK) Health and Safety Executive (HSE) on loading arm had provided the probabilities of failures, and the possible size of hole such as guillotine break or 0.1 cross sectional area of pipe. This information, with ammonia operational parameters such as internal and external pressure and ammonia liquid flow rate we can thus predict the amount of ammonia release. Combining with meteorological data information, local landscape conditions and utilizing ALOHA software, we are able to simulate ammonia dispersion and thus predicting the impact of toxicity of ammonia release on the population within the area. This paper is a feasibility study that use modelling approaches to manage ammonia leakage.
\end{abstract}

Keywords: Ammonia, Loading Arm, ALOHA, Failure Rate

\section{Introduction}

Ammonia is one of the bulk liquid dangerous cargoes for export through the ports or terminals. It is loaded to vessel by loading arm, a safe and efficient way of ammonia transfer from wharf to the vessel. Ammonia is a bulk liquid risky cargo that can be shipped through ports or terminals. It is loaded onto the vessel using a loading arm, which is a safe and effective method of transferring ammonia from the wharf to the vessel. The loading arm with automatic quick release in which it can disengaged the ship side and the land side. Loading arm have limited range vertically and horizontally and will also be activated once the range is exceeded. 
The loading arm has an automatic rapid release that allows it to disconnect the ship and land sides. The vertical and horizontal range of the loading arm is limited, and it will be activated if the range is exceeded. Because the loading activity is taking place within the port's inner harbour, there is a chance of ammonia leakage or discharge into the atmosphere, which could impact the population. Since the loading operation is within the inner harbour of the port, there is concern about the risk of ammonia leak or release into the atmosphere, potentially affecting the population around the port (Rajeev et al., 2019). There were concerns whether there is a need to provide proper toxic shelter or refuge as a mitigation measures (Tarkington et al., 2009) whenever there is an ammonia accidental release. Because the loading process is taking place within the port's inner harbour, there is a possibility of ammonia leakage or release into the atmosphere, potentially endangering the port's surrounding population. There have been questions over whether sufficient poisonous shelter or refuge should be provided as a mitigating mechanism if ammonia is accidentally released.

\section{Behaviour of Ammonia Upon Release}

Ammonia is a colourless, lighter-than-air gas with a strong odour. At $-330{ }^{\circ} \mathrm{C}$, it becomes liquid. When ammonia is released into the air, it can behave in three ways: as a superheated liquid, a pressurised liquid under boiling point, or a gas (Che Hassan et al., 2009). When liquid ammonia is discharged into the environment, it transforms and vaporises, generating a moving cloud. The migration is influenced by factors such as wind speed, direction, pasquil stability, temperature, and relative humidity in the environment (Che Hassan et al., 2009). As a result, simulations of migration from the starting condition to the expected ultimate locations are required. The inventory of releases, pipeline temperature, leak source or mechanism, surface type, roughness, internal pressure, ambient pressure, and temperature will all influence this (Abbaslou \& Karimi, 2019).

\section{Simulation Software}

Various studies and various software had been used for simulation. For this study, ALOHA is use as it is free; thus, it is widely used by experts, organizations, and departments. Lee et al. (2018) indicated that ALOHA is the best simulator for the determination of ammonia toxicity.

\section{Toxic Effect of Ammonia upon Release}

When an event involving hazardous chemicals occurs, ALOHA utilises Acute Exposure Levels (AEGL) as toxic Levels of Concern. ALOHA will create threat zones that are denoted by the colours yellow, orange, and red. As a rule of thumb, the modelling assumes a 60-minute exposure length as the default LOC. The three AEGL tiers are defined as follows:

- AEGL-3 is the concentration of a material in the air, defined in parts per million (ppm) or milligrammes per cubic metre $\left(\mathrm{mg} / \mathrm{m}^{3}\right)$, at which the general population, including vulnerable people, is expected to incur life-threatening health effects or death.

- AEGL-2 is the airborne concentration (expressed as $\mathrm{ppm}$ or $\mathrm{mg} / \mathrm{m}^{3}$ ) of a substance above which it is predicted that the general population, including susceptible individuals, could experience irreversible or other serious, long-lasting adverse health effects or an impaired ability to escape.

- AEGL-1 The airborne concentration (in $\mathrm{ppm}$ or $\mathrm{mg} / \mathrm{m}^{3}$ ) of a material at which the general public, including susceptible people, is expected to feel noticeable pain, irritation, or certain asymptomatic nonsensory effects. The effects, however, are not crippling and are temporary and reversible if the exposure is terminated. 
There are studies about ammonia exposure and effect on human (Table 1A) and (Table 1B).

Table 1A: Signs and Symptoms on Ammonia Exposure to Human

\begin{tabular}{|c|c|c|}
\hline Exposure (ppm) & Signs and Symptoms & \\
\hline References & (Murphy, 2007) & $\begin{array}{l}\text { The Fertilizer Institute - Health and } \\
\text { Effect of Ammonia }\end{array}$ \\
\hline 50 & $\begin{array}{l}\text { Irritation to eyes, nose and } \\
\text { throat ( } 2 \text { hours exposure) }\end{array}$ & Mild discomfort \\
\hline 100 & $\begin{array}{l}\text { Rapid eye and respiratory } \\
\text { tract irritation }\end{array}$ & Nuisance to eyes and throat irritation \\
\hline 250 & $\begin{array}{l}\text { Tolerable by most people } \\
\text { (30-60 minutes exposure) }\end{array}$ & \\
\hline 700 & $\begin{array}{l}\text { Immediately irritating to } \\
\text { eye and throat }\end{array}$ & \\
\hline $700-1700$ & & $\begin{array}{l}\text { Incapacitation from tearing of eyes and } \\
\text { coughing }\end{array}$ \\
\hline$>1500$ & $\begin{array}{l}\text { Pulmonary oedema, } \\
\text { coughing }\end{array}$ & \\
\hline $2500-4500$ & $\begin{array}{l}\text { Fatal (30 minutes } \\
\text { exposure) }\end{array}$ & \\
\hline Less 5000 & & $\begin{array}{l}\text { Usually, recovery without pulmonary } \\
\text { complication }\end{array}$ \\
\hline $5000-10000$ & $\begin{array}{l}\text { Rapid fatal due to highway } \\
\text { obstruction, may cause skin } \\
\text { damage }\end{array}$ & Fatalities due to obstruction of airways \\
\hline
\end{tabular}

Table 1B: Signs and Symptoms on Ammonia Exposure (ANSI/CGA G-2.1-2014)

\begin{tabular}{|l|l|}
\hline Concentration/Time & Effect \\
\hline $20 \mathrm{ppm}$ to $50 \mathrm{ppm}$ & $\begin{array}{l}\text { Mild discomfort, depending on whether an individual is } \\
\text { accustomed to smelling ammonia }\end{array}$ \\
\hline $\begin{array}{l}50 \mathrm{ppm} \text { to } 80 \mathrm{ppm} \text { for } 2 \\
\text { hours }\end{array}$ & Perceptible eye and throat irritation \\
\hline $100 \mathrm{ppm}$ & Nuisance eve and throat irritation \\
\hline $134 \mathrm{ppm}$ for 5 minutes & $\begin{array}{l}\text { Tearing of the eyes, eye irritation, nasal irritation, throat } \\
\text { irritation, chest irritation }\end{array}$ \\
\hline $140 \mathrm{ppm}$ for 2 hours & Severe irritation, need to leave the exposure areas \\
\hline $\begin{array}{l}300 \mathrm{ppm} \text { to } 500 \mathrm{ppm} \text { for } 30 \\
\text { minutes }\end{array}$ & $\begin{array}{l}\text { Upper respiratory tract irritation; tearing of the eyes } \\
\text { (lacrimation), hyperventilation }\end{array}$ \\
\hline $700 \mathrm{ppm}$ to $1700 \mathrm{ppm}$ & Incapacitation from tearing of eyes \\
\hline $5000 \mathrm{ppm}$ to $10000 \mathrm{ppm}$ & Rapidly fatal \\
\hline $10000 \mathrm{ppm}$ & Promptly fatal \\
\hline
\end{tabular}

From the above data and based on EPA guidelines for ammonia AEGL (National Research Council, 2008) gives the following data: 
Table 2: AEGL For Different Durations

\begin{tabular}{|l|l|l|l|}
\hline Classification & 10 minutes & 30 minutes & 1 hour \\
\hline AEGL 1 & $30 \mathrm{ppm}$ & $30 \mathrm{ppm}$ & $30 \mathrm{ppm}$ \\
\hline AEGL 2 & $220 \mathrm{ppm}$ & $220 \mathrm{ppm}$ & $160 \mathrm{ppm}$ \\
\hline AEGL 3 & $2700 \mathrm{ppm}$ & $1600 \mathrm{ppm}$ & $1100 \mathrm{ppm}$ \\
\hline
\end{tabular}

As a result, the following figure was used for simulation purposes:

- AEGL 1 is 30 ppm - based on EPA guidelines for ammonia AEGL.

- AEGL 2 is 200 ppm - in the case of evacuating personnel, and from ANSI/CG

- AEGL 3 is 5000 ppm - deadly and instant mortality - for risk assessment

\section{The Loading Arm}

The loading arm is a mechanical device that was created to aid in transportation of liquid cargo from the wharf to the ship or vessel. Loading arm can be specified/designed to account for tanker movement during loading and unloading owing to tides, waves, and wind, as well as the tanker's cargo increasing or decreasing. Each loading arm is built to operate within a specific 'envelope.' If a coupled loading arm is pushed beyond of this range, it should be detached right away (manually or, for some systems, automatically). The most important aspects to consider are Tanker DWT, tidal range, maximum wave height, jetty structure elevation, and the size/number of loading arms at the berth are all factors that influence the required operating envelope (Figure 1 ).

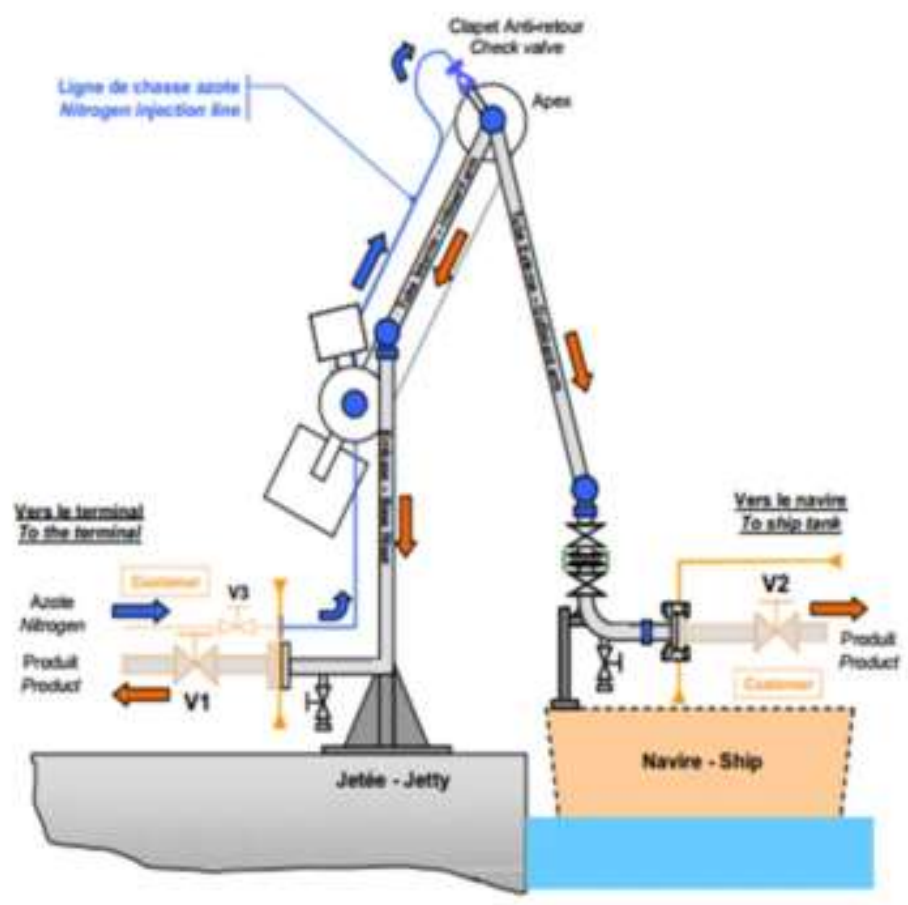

Figure 1: The loading arm to aid in transportation of liquid cargo from the wharf (Anup, K. D., n.d.).

\section{Failure Mode of Loading Arm}

Failure of the loading arm will cause the liquid to leak or release to the atmosphere (Table 3). In order to determine the amount of release, thus the failure mode had to be determined. The area of hole of release will determine the flow rate and the pressure of the liquid into the atmosphere. HSE Executive, UK had summarized and determine that the failure mode are 
guillotine failure, that is the liquid release with the area of the cross sectional area of the pipe, and 0.1 of the cross sectional area of the pipe. (Health and Safety Executive, 2017) This will be the basis to determine the flowrate of the liquid into the atmosphere. The ammonia properties to be included in determining the flowrate are the operational pressure of 6 Bar, Atmospheric pressure of $1 \mathrm{Bar}$, the liquid temperature of $-33^{\circ} \mathrm{C}$. Specific gravity of 0.681 for ammonia (Kaczmarek et al., 2014)

The leak rate equation is:-

$$
\begin{aligned}
& Q=C A\{2 A P /(S P w, s t d)\}^{-1 / 2} \\
& A=\text { area of hole or crack } \\
& C=\text { Discharge coefficient, need } 0<C<1 \\
& S=\text { Liquid specific gravity. } \\
& P=\text { water } \mathrm{sp} \\
& \Delta P=\text { Pressure drops from inside to outside of pipe }\left(\mathrm{N} / \mathrm{m}^{2}\right) \\
& Q=\text { Flowrate of the leak in } \mathrm{m} / \mathrm{s}
\end{aligned}
$$

Table 3: Failure Mode Parameters for Loading Arm

\begin{tabular}{|c|c|c|c|c|}
\hline Parameters & $\begin{array}{l}\text { Scenario } \\
1\end{array}$ & $\begin{array}{l}\text { Scenario } \\
2\end{array}$ & $\begin{array}{l}\text { Scenario } \\
3\end{array}$ & $\begin{array}{l}\text { Scenario } \\
4\end{array}$ \\
\hline $\begin{array}{l}\text { Wind } \\
\text { Direction }\end{array}$ & $\begin{array}{l}\text { East } \\
\text { (E) }\end{array}$ & $\begin{array}{l}\text { South-East } \\
\text { (SE) }\end{array}$ & $\begin{array}{l}\text { North-West } \\
\text { (NW) }\end{array}$ & $\begin{array}{l}\text { North } \\
\text { (N) }\end{array}$ \\
\hline $\begin{array}{l}\text { Wind Speed } \\
\text { (meter per } \\
\text { second) }\end{array}$ & 1.5 & 1.5 & 3.0 & 4 \\
\hline $\begin{array}{l}\text { Pasquill } \\
\text { atmospheric } \\
\text { stability } \\
\text { classes }\end{array}$ & $\begin{array}{l}\text { F } \\
\text { Stable }\end{array}$ & $\begin{array}{l}\text { F } \\
\text { Stable }\end{array}$ & $\begin{array}{l}\text { E } \\
\text { Slightly Stable }\end{array}$ & $\begin{array}{l}\text { D } \\
\text { Neutral }\end{array}$ \\
\hline $\begin{array}{l}\text { Temperature } \\
(\mathrm{oC})\end{array}$ & 35 & 35 & 35 & 35 \\
\hline Humidity (\%) & 80 & 80 & 80 & 80 \\
\hline
\end{tabular}

\begin{tabular}{|l|l|l|}
\hline Failure Mode & $\begin{array}{l}\text { Guillotine (Total cross- } \\
\text { sectional area) }\end{array}$ & $\mathbf{0 . 1}$ cross sectional area \\
\hline Diameter $(\mathrm{m})$ & 0.0762 & 0.0762 \\
\hline Area $\left(\mathrm{m}^{2}\right)$ & 0.004558055 & 0.00045581 \\
\hline Pressure $(\mathrm{Pa})$ & 600000 & 600000 \\
\hline External Pressure $(\mathrm{Pa})$ & 100000 & 100000 \\
\hline Coefficient C & 0.61 & 1.61 \\
\hline Discharge Rate Q $\left(\mathrm{m}^{3} / \mathrm{s}\right)$ & 0.106545688 & 0.01789871 \\
\hline Specific gravity & 0.681 & 1.681 \\
\hline
\end{tabular}

\section{Metrological condition}

Metrological data was obtained from Metrological Department Malaysia, and the wind data are as follows (Table 4).

Table 4: Metrological Conditions On 4 Scenarios of Ammonia Leakage from Metrological Department Malaysia Bintulu Station 2010-2019 


\section{Simulation Software}

Various studies and various software had been used for simulation. For this study, ALOHA is use as it is free; thus, it is widely used by experts, organizations, and departments. Lee et al. indicated that ALOHA is the best simulator for the determination of ammonia toxicity (Lee et al., 2018). ALOHA based its simulation on Gaussian Distribution for the migration of vapour cloud. The simulation outputs for four scenarios shown in Figure 2.

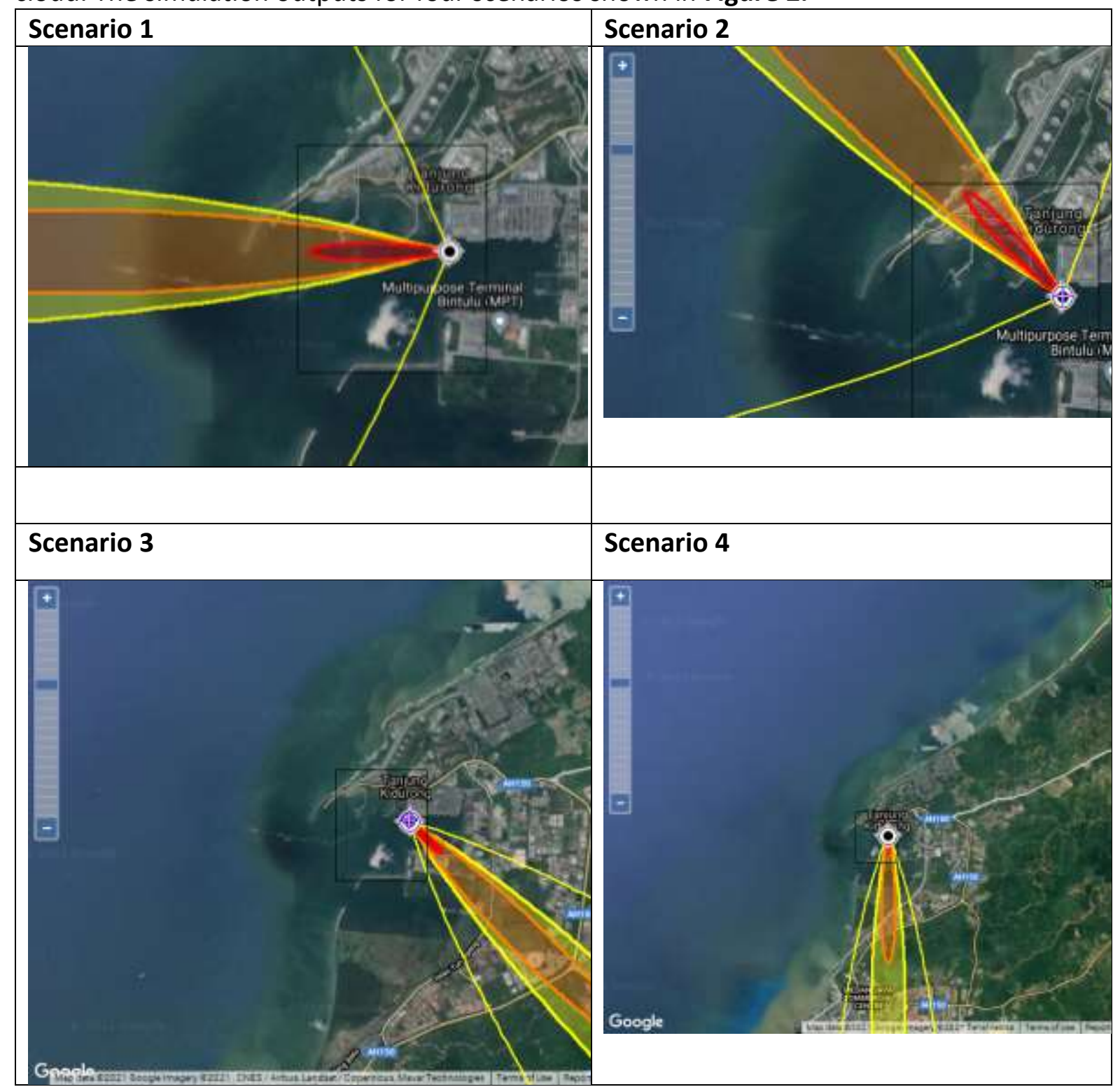

Figure 2: Simulated ammonia dispersion based on four scenarios from Table 4

\section{Risk Assessment on Ammonia Release at The Port}

Failure rates are a valuable tool for determining the viability of a plan or project, as well as for understanding the problem in the sector. People will have to weigh the threat against the mode of failure's projected failure rate. Risk assessment may be performed, and conclusions derived from this information and the consequence report as shown above through the three tiers. 


\section{Probability of Failure}

The probability of incident as illustrated by HSE Executive for single loading arm (Health and Safety Executive, 2017) as follows: -

- Guillotine failure: 7 × 10-6 per operation

- 0.1 Cross sectional area of pipe: $8 \times 10^{-6}$ per operation

\section{Guillotine Break}

Failure rate for guillotine break is $7 \times 10^{-6}$ per transfer.

For a monthly transfer, for 3 days per year, the probability of failure is

$3 / 365 \times 12 \times 7 \times 10^{-6}$ year $=6.9 \times 10^{-7}$ per year

Hole $\mathbf{= 0 . 1}$ cross sectional area of pipe

Pipe diameter $=3$ inches $=750 \mathrm{~mm}$.

Failure rate for one arm $=8 \times 10^{-6}$ per year

One 3-day operation per month will have the failure rate of $3 / 365 \times 12 \times 8 \times 10^{-6}=7.89 \times 10$ -

7 per year

\section{Risk of the event (Probability of Loss of Life)}

For the four scenarios, the risk is summarised as below (Table 5): -

Table 5: Individual Risk Based on 4 Scenario of Failures

\begin{tabular}{|c|c|c|c|c|c|c|c|c|}
\hline $\begin{array}{l}\text { Parameter } \\
\text { s }\end{array}$ & $\begin{array}{l}\text { Scenario } \\
1\end{array}$ & & $\begin{array}{l}\text { Scenario } \\
2\end{array}$ & & $\begin{array}{l}\text { Scenario } \\
3\end{array}$ & & $\begin{array}{l}\text { Scenario } \\
4\end{array}$ & \\
\hline Failures & $\begin{array}{l}\text { Guillotin } \\
\mathrm{e}\end{array}$ & $\begin{array}{l}0.1 \\
\text { Cross } \\
\text { Section } \\
\text { al Area }\end{array}$ & $\begin{array}{l}\text { Guillotin } \\
\mathrm{e}\end{array}$ & $\begin{array}{l}0.1 \\
\text { Cross } \\
\text { Section } \\
\text { al Area }\end{array}$ & Guillotin & $\begin{array}{l}0.1 \\
\text { Cross } \\
\text { Section } \\
\text { al Area }\end{array}$ & e & $\begin{array}{l}0.1 \\
\text { Cross } \\
\text { Section } \\
\text { al Area }\end{array}$ \\
\hline Population & 100 & 100 & 100 & 100 & 181 & 181 & 181 & 181 \\
\hline $\begin{array}{l}\text { Probability } \\
\times 10^{-7} \text { per } \\
\text { year }\end{array}$ & 6.9 & 7.89 & 6.9 & 7.89 & 6.9 & 7.89 & 6.9 & 7.89 \\
\hline $\begin{array}{l}\text { Percentag } \\
\text { e of wind } \\
\text { direction } \\
\text { (\%) }\end{array}$ & 24.9 & 24.9 & 21.1 & 21.1 & 12.0 & 12.0 & 9.6 & 9.6 \\
\hline $\begin{array}{l}\text { Individual } \\
\text { Risk } \\
\text { X } 10^{-5} \text { per } \\
\text { year }\end{array}$ & 1.71 & 1.96 & 1.45 & 1.66 & 1.49 & 1.71 & 1.19 & 1.37 \\
\hline
\end{tabular}

This is an estimate that the toxicity of ammonia within the area is below the mortality rate. HSE Executives UK's Individual Risk Criteria (Det Norske Veritas,2002) provide guidelines on acceptable limit.

- Maximum tolerable risk for workers $10^{-3}$ per person per year

- Maximum tolerable risk for public $10^{-4}$ per person per year

It is thus concluded that the risk using the loading arm with the current control is acceptable. 


\section{Conclusion}

Simulation software support management in determining the acceptable control measure taken for ammonia loading in the port. The simulation software requires metrological data and operational data to provide simulated zones of interest. Using ALOHA which is free and acceptable to be used to simulate ammonia release gives zones in AEGL. This study will be considering the individual tolerable risk. Using a loading arm as the mode of transfer of ammonia from land to vessel, it was indicated that the process it is below the tolerable risk for workers and the public based on failure mechanism as indicated by HSE Executives. Future research should focus on operational failures, such as leakage, which are more likely to occur (Vílchez et al., 1995). The programme will make it easier to figure out how much leakage there is and where the areas of concern are (Haastrup \& Brockhoff, 1990).

\section{References}

Abbaslou, H., \& Karimi, A. (2019). Modeling of Ammonia Emission in the Petrochemical Industry. Jundishapur Journal of Health Sciences, 11(3). https://doi.org/10.5812/jjhs.94101

Anup, K. D. (n.d.) Introduction to Marine Loading Arm. Retrieved 21 September 2021. https://whatispiping.com/marine-loading-arm/

Che Hassan, C., Puvaneswaran, B., Abdul Raman, A., Mahmood, N., Hung, F., Sulaiman, N., Puvaneswaran, A., \& Balasubramaniam, L. (2009). A case study of consequences analysis of ammonia transportation by rail from Gurun to Port Klang in Malaysia using Safti computer model. Journal of Safety Health \&Environmemt Research, 6, 1-19.

Det Norske Veritas. (2002). Marine risk assessment, Health and Safety Execuitve Offshore Technology Report 2001/063. Retrieved from https://www.hse.gov.uk/research/otopdf/2001/oto01063.pdf.

National Research Council. (2008). Acute Exposure Guideline Levels for Selected Airborne Chemicals. Washington, DC: The National Academies Press. https://doi.org/10.17226/12018

Haastrup, P., \& Brockhoff, L. (1990). Severity of accidents with hazardous materials. A comparison between transportation and fixed installations. Journal of Loss Prevention in the Process Industries, 3(4), 395-405. https://doi.org/10.1016/0950-4230(90)80010-8

Health and Safety Executive. (2017). Failure Rate and Event Data for use within Risk Assessments (06/11/17). 102.

Kaczmarek, R., Radzikowska, E., \& Baraniak, J. (2014). The facts about ammonia. Synlett, 25(13), 1851-1854. https://doi.org/10.1055/s-0034-1378353

Lee, H. E., Sohn, J. R., Byeon, S. H., Yoon, S. J., \& Moon, K. W. (2018). Alternative risk assessment for dangerous chemicals in South Korea regulation: Comparing three modeling programs. International Journal of Environmental Research and Public Health, 15(8), 1-12. https://doi.org/10.3390/ijerph15081600

Murphy, D. B. (2007). Ammonia: Toxicological Overview. Public Health England, November, 1-15.

Rajeev, K., Soman, S., Renjith, V. R., \& George, P. (2019). Human vulnerability mapping of chemical accidents in major industrial units in Kerala, India for better disaster mitigation. International Journal of Disaster Risk Reduction, 39.

https://doi.org/10.1016/j.ijdrr.2019.101247

Tarkington, B., Harris, A. J., Barton, P. S., Chandler, B., \& Goad, P. T. (2009). Effectiveness of common shelter-in-place techniques in reducing ammonia exposure following accidental 
INTERNATIONAL JOURNAL OF ACADEMIC RESEARCH IN BUSINESS AND SOCIAL SCIENCES

Vol. 11, No. 17, Empowering Community and Beyond, iRandau, 2021, E-ISSN: 2222-6990 @ 2021 HRMARS

release. Journal of Occupational and Environmental Hygiene, 6(4), 248-255. https://doi.org/10.1080/15459620902746857

Vílchez, J. A., Sevilla, S., Montiel, H., \& Casal, J. (1995). Historical analysis of accidents in chemical plants and in the transportation of hazardous materials. Journal of Loss Prevention in the Process Industries, 8(2), 87-96. https://doi.org/10.1016/09504230(95)00006-M 